\title{
Age and growth of the Dolphinfish Coryphaena hippurus in the coast of Oaxaca and Chiapas, Mexico
}

\author{
Edad y crecimiento del dorado Coryphaena hippurus en la costa de Oaxaca y Chiapas, México
}

\section{Mauricio Solano-Fernández ${ }^{1}$, José Alberto Montoya-Márquez², Manuel Gallardo-Cabello ${ }^{3}$ and Elaine Espino-Barr ${ }^{4}$}

\author{
'Biología Marina, Universidad del Mar, Puerto Ángel, Oaxaca, México \\ ${ }^{2}$ Instituto de Recursos, Universidad del Mar, Puerto Ángel, Oaxaca, México, Ciudad Universitaria s/n. Puerto Ángel, Oaxaca, \\ C.P. 70902, México \\ ${ }^{3}$ Instituto de Ciencias del Mar y Limnología, Universidad Nacional Autónoma de México, Av. Ciudad Universitaria 3000, \\ Col. Copilco, México, D.F. C.P. 04360, México \\ ${ }^{4}$ INAPESCA, CRIP-Manzanillo. Playa Ventanas s/n, Manzanillo, Colima. C.P. 28200, México. elespino@gmail.com
}

\begin{abstract}
Resumen.- Se observaron los incrementos de crecimiento diarios en los otolitos del dorado (Coryphaena hippurus) en la costa de Oaxaca y Chiapas, en el Pacífico centro mexicano, entre septiembre 2004 y septiembre 2005. Los anillos de crecimiento diario en las sagittae, se muestran principalmente en la zona del pararostrum. No se encontraron anillos de crecimiento de una periodicidad mayor a los incrementos de crecimiento diario. Consideramos que este método es ideal para identificar anillos de crecimiento diarios en organismos jóvenes. Conforme crece el espécimen, la amplitud del anillo de crecimiento disminuye, por lo que estos anillos pueden subestimarse por traslape en organismos viejos. El modelo de crecimiento de Gompertz describió mejor la primera fase de crecimiento $\left(L_{0}=7,02, G=3,04, g=2,89\right)$. El método de ajuste de máxima verosimilitud al modelo de von Bertalanffy fue el que mejor se ajustó a los valores observados: $L_{\infty}=$ $231,65 \mathrm{~cm}, \mathrm{~W}_{\infty}=77,926 \mathrm{~kg}, \mathrm{~K}=0,874, \mathrm{t}_{0}=0,074$. La longevidad fue de 3,44 años. La relación longitud-peso y el factor de condición de los machos $\left(\mathrm{W}=2,154 \cdot 10^{-5} \cdot \mathrm{L}^{2,788}, \mathrm{CF}_{\mathrm{r}}=1,04\right)$ mostraron valores más elevados que en las hembras $\left(\mathrm{W}=4,608 \cdot 10^{-5} \cdot \mathrm{L}^{2,586}, \mathrm{CF}_{\mathrm{r}}=\right.$ $0,96)$, debido posiblemente a un mayor peso de los machos por la presencia de la cresta ósea.
\end{abstract}

Palabras clave: Incrementos de crecimiento diario, sagitta, von Bertalanffy, Gompertz, Pacífico mexicano

\begin{abstract}
Daily growth increments were analyzed in otoliths of Dolphinfish (Coryphaena hippurus) in the coasts of Oaxaca and Chiapas, on the central Mexican Pacific, from September 2004 to September 2005. Results showed that it is possible to count daily growth rings in the sagittae, mainly on the pararostrum zone. Seasonal growth rings were not detected, that is, longer than daily periodicity. We consider that this method is ideal to identify daily growth rings in young organisms. As specimen age and the amplitude of the growth rings diminish, these rings can be underestimated because they appear to overlap. The Gompertz growth model best described the first growth phase $\left(L_{0}=7.02, G=3.04, g=2.89\right)$, and the von Bertalanffy constants were: $\mathrm{L}_{\infty}=231.65 \mathrm{~cm}, \mathrm{~W}_{\infty}=77.926 \mathrm{~kg}, \mathrm{~K}=0.874, \mathrm{t}_{0}=0.074$. The longevity was estimated at 3.44 years. Sexual dimorphism results in differences in the weight-length relationship and the relative condition factor with males $\left(\mathrm{W}=2.154 \cdot 10^{-5} \cdot \mathrm{L}^{2.788}, \mathrm{CF}_{\mathrm{r}}=1.04\right)$ having higher values than females $\left(\mathrm{W}=4.608 \cdot 10^{-5} \cdot \mathrm{L}^{2.586}, \mathrm{CF}_{\mathrm{r}}=0.96\right)$, due to the presence of the bony crest in males.
\end{abstract}

Key words: Daily growth increments, sagitta, von Bertalanffy, Gompertz, Mexican Pacific

\section{INTRODUCTION}

The Dolphifish or Dorado Coryphaena hippurus Linnaeus, 1758, is found in all the tropical and subtropical latitudes, generally limited by the $20^{\circ} \mathrm{C}$ isotherm (Palko et al. 1982). Kojima (1964) suggested that in the Pacific Ocean C. hippurus are found year round between latitudes of $30^{\circ} \mathrm{N}$ and $30^{\circ} \mathrm{S}$, in surface waters with temperatures from 21 to $30^{\circ} \mathrm{C}$ and salinities of 31 . This species is a fast swimmer and presents high reproductive and growth rates (Palko et al. 1982).
C. hippurus is an appreciated species and targeted by established fisheries worldwide. Its capture in 1999 was between 20,000 and 40,000 metric tons (Cannizzaro et al. 1999), by 2013 in increased to over 100,000 metric tons (FAO 2015). In Mexico the fishery of $C$. hippurus is regulated by the NOM-PESC-017-1994, which reserves the use of this species for sport fishing within 50 miles of the coastline. Officially there is no commercial fishery directed to the capture this species, but the resource is exposed to by-catch in other fisheries (artisanal and tuna fish) (DOF 2004). 
In Mexico, $C$. hippurus is caught with hook and line, Tuna troller and in other occasions with seines or trawl nets (Espino-Barr et al. 2003). Fish aggregation devices have also been used before installing the fishing nets and some fisheries use different sizes and types of hooks, taking advantage of its grouping behavior, which allows for increased catches (Palko et al. 1982).

C. hippurus is a long compressed fish, characterized by a large mouth and fine teeth arranged in rows. Dorsal and anal fins are long and without tapered spines, pelvic fins fold into a groove of the body, and the caudal fin is deeply forked. It has small cycloid scales and the lateral line form an arch over the pectoral fin. The color is variable; the sides have golden reflections, the back and side greenish and bright metallic blue with several black spots on the head and body (Fischer et al. 1995). The species exhibits sexual dimorphism, in the form of the head: males have a tall bony crest, while females have a low sloped forehead. Males develop the crest at about $40 \mathrm{~cm}$ fork length (Palko et al. 1982). Sexual maturity for both sexes is reached in the first year of life (Beardsley 1967, Scherbachev 1973). Barcelata-Ortiz et al. (1990) report a length of first maturity in both sexes of $C$. hippurus in Mazatlan, at $44.00 \mathrm{~cm}$ fork length.

C. hippurus is a quick and agile predator of other fish and cephalopods (Cannizzaro et al. 1999), therefore considered an opportunistic predator (Palko et al. 1982).

Studies have been made on its biology and growth analysis by different authors: the first study on the growth of the Dolphinfish was of Beardsley (1967) in the coast of Florida and of Rose \& Hassler (1968) North Carolina, both based on scale readings. Massutí et al. (1999) analyzed otoliths of the Dolphinfish in the Western Mediterranean, based mainly in the daily growth ring identification and microstructure identification. Schwenke \& Buckel (2008) studied the Dolphinfish from North Carolina providing data on age and growth marks in otoliths and scales, also growth and reproduction of this species. Alejo-Plata et al. (2011) studied the Dolphinfish from the coasts of Oaxaca, reporting data on growth ring identification in scales, growth analysis and reproductive periods.

Pla \& Pujolar (1999) analyzed the genetic homogeneity of the Dolphinfish in Western Mediterranean and Eastern Atlantic. Díaz-Jaimes et al. (2006) and Rocha Olivares et al. (2006) studied the genetic and population structure determined by the mitochondrial DNA analysis, and TrippValdez et al. (2010) were able to detect differences in the allele frequencies in samples of $C$. hippurus from the Gulf of California, in which there was no observed heterogeneity.

Studies on age and growth provide the data necessary to calculate parameters of the von Bertalanffy growth equation (1938), which can then be used to estimate maximum sustainable yield, and simulate catches, that lead to improved fish management (Espino-Barr et al. 2008).

The objectives of this study were to identify and count daily growth increments in the sagittae otoliths, describe the sagittae shape using morphometric measurements, analyze weight-length relationships, formulate growth equations including the Gompertz equation (1825); analyze aspects of the relative condition factor, determine longevity and compare these results to those obtained for this species in Mexico and other countries by other authors.

\section{MATERIALS AND METHODS}

On a monthly basis from September 2004 to September 2005, 210 organisms of Coryphaena hippurus were taken directly from the incidental captures and sport fishery at the coast of Oaxaca state localities of Puerto Escondido (15 $51^{\prime} 38^{\prime \prime} \mathrm{N}, 97^{\circ} 03$ '51'”W), Puerto Ángel (15'39'57' $\mathrm{N}$, $\left.96^{\circ} 29^{\prime} 25^{\prime \prime} \mathrm{W}\right)$, Huatulco $\left(15^{\circ} 45^{\prime} 40^{\prime \prime} \mathrm{N}, 9^{\circ} 04^{\prime} 36^{\prime \prime} \mathrm{W}\right)$, and Salina Cruz (16 $09^{\prime} 59^{\prime \prime} \mathrm{N}, 95^{\circ} 10^{\prime} 22^{\prime}$ 'W), and in Chiapas state in the locality of Puerto Madero $\left(14^{\circ} 42^{\prime} 57^{\prime \prime} \mathrm{N}\right.$, $\left.92^{\circ} 25^{\prime} 14^{\prime \prime} \mathrm{W}\right)$.

Fork length (FL) was measured from the tip of the mouth to the tail fork, using a flexible tape $1.00 \mathrm{~m}$ in length and with $0.50 \mathrm{~cm}$ increments. Sex was determined based on external characteristics of the head. To obtain the weight, an Ohaus CS5000 balance was used for small organisms and an Intercomp CS 200 balance with a precision of $0.100 \mathrm{~kg}$ for the larger fish. The heads were cut, frozen and taken to the lab to extract the otoliths using the methods of Panella (1980) and Brothers (1987) as modified by Rivera \& Appeldorn (2000). One hundred and sixty five sagittae were extracted.

Length and width measurements of the otoliths were taken according to the technique of Lombarte \& Lleonart (1993) and Harvey et al. (2000), using a micrometric scale in the ocular of a Zeiss ${ }^{\circledR} 2000$ Axiolab microscope. To polish the otoliths, the method of Morales-Nin et al. (1999) was modified, using a series of Buehler abrasive paper with decreasing rugosity of $10.00 \mu \mathrm{m}$ to $3.00 \mu \mathrm{m}$, adding water during the polish and finishing with Buehler alumina 
paste of $0.30 \mu \mathrm{m}$. To simplify the growth rings count digital photographs were taken of the otoliths, using a Polaroid camera attached to a Zeiss microscope. Each sample was photographed at $40 \mathrm{X}$ magnification, to view the complete otolith, then at $100 \mathrm{X}$ to view the complete section which showed the growth rings, and finally at 200X magnification in order to count the growth increments. Due to the high magnification, these observations were photographed in sections and thereafter put together to obtain one image with the complete sequence, using the Image Pro Plus 5.0 (Image-Pro 2004) ${ }^{1}$. Daily increment readings were done on the same axis described by Morales-Nin et al. (1999). The otoliths were read by one reader twice in random order at different times, at least 2 weeks apart (Schwenke $\&$ Buckel 2008). If the difference between the first and second reading was higher than $10 \%$, a third count was carried out. The deposit of the growth rings in otoliths start the first day of life, and these rings are daily, therefore each was considered as one day (Uchiyama et al. 1986, Massutí et al. 1999).

The relationship of weight to length was examined using the potential equation (Ricker 1975):

$$
W=a F L^{b}
$$

where: $W=$ total weight of fish $(\mathrm{g}), F L=$ fork length $(\mathrm{cm})$, $a=$ intercept, and $\mathrm{b}=$ slope.

The least squares method from Montgomery et al. (2004) was used to determine the best fit. A $t$-student test at $95 \%$ confidence level (Zar 1996) was used to examine the slope estimate $(b)$ of the weight-length equation for males, females and sex combined, and the standard error of the slope calculated according to Montgomery et al. (2004). Comparisons of the weight-length relationship between localities and by sex and season using a one way Covariance analysis, at $a=0.05$ (Zar 1996).

A relative condition factor $\left(\mathrm{CF}_{\mathrm{r}}\right)$ was calculated for all samples and per sex, locality and season (Weatherley \& Gill 1987). To compare the condition factor per sex a one way variance analysis (ANOVA) was applied. For the spatial analysis, a two way ANOVA was used with $a=$ 0.05. All the localities were first considered individually, thereafter those that were near were combined to create two zones for further analysis (Scheffé test, according to Zar 1996). The temporal analysis was carried out considering two seasons according to García-Nava
(2003): dry season (from November to April) and rainy season (from May to October). To check assumptions of the ANOVA, a residual analysis for the lineal model was applied (Dobson 2002), if there were significant differences, a test of multiple comparison of Tukey at 95\% was carried out (Zar 1996).

The precision of the daily growth readings was measured using the method of Chang (1982), that calculates the coefficient of variation $(\mathrm{V})$ and the index of precision (D).

To estimate the von Bertalanffy growth model parameters methods found in Ford (1933), Walford (1946) and Gulland \& Holt (1959) were used as well as the Levenberg-Marquardt method in Statistica (StatSoft $2001)^{2}$ and a maximum likelihood method from Kirkwood (1983). To find which method better fit the observed data, the sum of squared differences (SD) was used (Montgomery et al. 2004).

To compare the values of the asymptotic length $\left(\mathrm{L}_{\infty}\right)$ and growth rate index $(\mathrm{K})$ obtained in this study with those in other studies; a phi prima test ( $\left.\Phi^{\prime}\right)$ was used (Sparre \& Venema 1997):

$$
\Phi^{\prime}=\log K+2 \log L_{\infty}
$$

Also, the modified length growth model of Gompertz was used (Ricker 1975) with the Fishparm program (Prager 1987), the equation is:

$$
L_{t}=L_{0} \times e^{G\left(1-e^{-g t}\right)}
$$

where: $\mathrm{L}_{\mathrm{t}}=$ length at a given time $t, \mathrm{~L}_{0}=$ body length at time $0, \mathrm{G}=$ instantaneous growth rate at time $0, \mathrm{t}=$ age of the organism, $g=$ growth rate of $\mathrm{G}$.

All statistical tests were done with a confidence level of $95 \%$ and in the Statistica program ver. 6.9 for Windows XP (StatSoft 2001), except the likelihood analysis that was done using Excel 2003.

Weight at age was obtained using the weight-length function and substituting fork length $\left(\mathrm{L}_{\mathrm{t}}\right)$ for asymptotic length $\left(\mathrm{L}_{\infty}\right)$ and total weight $\left(\mathrm{W}_{\mathrm{t}}\right)$ for asymptotic weight $\left(\mathrm{W}_{\infty}\right)$, in von Bertalanffy's equation (1938). Age limit or longevity $\left(95 \%\right.$ of $\mathrm{L}_{\infty}$ ) was determined with Taylor's equation (1959):

$$
\mathrm{A}=\mathrm{t}_{\mathrm{o}}+(2.996 / \mathrm{K})
$$

${ }^{1}$ Image-Pro. 2004. Image Pro Plus Version 5.0. Media Cybernetics. Silver Spring.

${ }^{2}$ StatSoft Inc. 2001. STATISTICA (data analysis software system), version 6. <www.statsoft.com> 


\section{ReSUltS}

\section{LENGTH AND WEIGHT CHARACTERISTICS}

Data used in this study were from 210 individuals, their fork lengths were from $37 \mathrm{~cm}$ to $135 \mathrm{~cm}$, their weights from $0.53 \mathrm{~kg}$ to $24.00 \mathrm{~kg}$ (Table 1 ).

The weight-length relation was: $\mathrm{W}=\left(2.45 \cdot 10^{-5}\right) \cdot \mathrm{FL}^{2.75}$, $\mathrm{n}=210, \mathrm{R}^{2}=0.98, \mathrm{SD}^{2}=387.41$ (Fig. 1 ).

The $t$ student test of the slope or regression coefficient $(\mathrm{b}=2.75)$ was negative $\left(\mathrm{t}_{(208)}=-9.01, P<0.05\right)$, indicating that $C$. hippurus grows more in length than in weight. No differences in the weight-length relationship were found between locations $\left(\mathrm{F}_{(4,200)}=0.799, P>0.05\right)$, nor between seasons $\left(\mathrm{F}_{(1,200)}=1.908, P>0.05\right)$.

Values of the allometric index among sexes were: $b=$ 2.586 in females and $b=2.788$ in males (Table 2) and both were negative $\left(\mathrm{t}_{(98)}=-10.10, P<0.05\right.$ in females and $\mathrm{t}_{(87)}=-$ $5.19, P<0.05$ in males). Covariance Analysis showed significant differences between sexes $\left(\mathrm{F}_{(1,185)}=11.486, P<\right.$ 0.05). The slope was higher in males than in females, meaning that there is a higher relative growth in weight in males.

The relative condition factor $\left(\mathrm{CF}_{\mathrm{r}}\right)$ for all the individuals was $\mathrm{CF}_{\mathrm{r}}=1.01(0.58-1.54, \mathrm{n}=210)$. Males had a $\mathrm{CF}_{\mathrm{r}}=1.04$ $(0.71-1.54, \mathrm{n}=91)$ and for females $\mathrm{CF}_{\mathrm{r}}=0.96(0.58-1.42, \mathrm{n}=$ 98). Males had a higher $\mathrm{CF}_{\mathrm{r}}$ than females $\left(\mathrm{F}_{(1,187)}=15.982, P\right.$ $<0.05)$.

Even though there was no significant difference between localities $\left(\mathrm{F}_{(4,205)}=2.395, P=0.05\right)$, there was an evident trend in the values (Fig. 2). The planned comparisons test (Scheffé test) showed two groups, which were classified as zone I: Puerto Escondido, Puerto Ángel, and Huatulco, and zone II: Salina Cruz and Puerto Madero $\left(\mathrm{F}_{(1,205)}=4.565\right.$, $P<0.05)$.

The two way analysis did not show significant differences in the interactions between zones and seasons $\left(\mathrm{F}_{(1,206)}=0.348, P>0.05\right)$, nor when considering the principal effect of season $\left(\mathrm{F}_{(1,206)}=0.306, P>0.05\right)$, but did show differences per zones $\left(\mathrm{F}_{(1,206)}=6.123, P<0.05\right)$. A higher $\mathrm{CF}_{\mathrm{r}}$ was observed in zone I (Fig. 3).

\section{OTOLITH MORPHOMETRY}

The sagittal otoliths of Dolphinfish are extremely small relative to the size of the fish (ratio between average fork length and average otolith length 1:266.51 mm).
Table 1. Length and weight of Coryphaena hippurus / Longitud y peso de Coryphaena hippurus

\begin{tabular}{lcccccc}
\hline & $\begin{array}{c}\text { All } \\
\text { individuals } \\
(\mathrm{cm})\end{array}$ & $\begin{array}{c}\text { All } \\
\text { individuals } \\
(\mathrm{kg})\end{array}$ & $\begin{array}{c}\text { Males } \\
(\mathrm{cm})\end{array}$ & $\begin{array}{c}\text { Females } \\
(\mathrm{cm})\end{array}$ & $\begin{array}{c}\text { Males } \\
(\mathrm{kg})\end{array}$ & $\begin{array}{c}\text { Females } \\
(\mathrm{kg})\end{array}$ \\
\hline Average & 82.81 & 6.21 & 94.09 & 68.53 & 8.38 & 3.54 \\
Minimum & 37.00 & 0.53 & 42.00 & 37.00 & 0.75 & 0.53 \\
Maximum & 135.00 & 24.00 & 135.00 & 118.00 & 24.00 & 12.40 \\
Mode & 103.00 & 12.00 & 103.00 & 44.00 & 12.00 & 9.97 \\
n & 210 & 210 & 90 & 100 & 90 & 100 \\
\hline
\end{tabular}

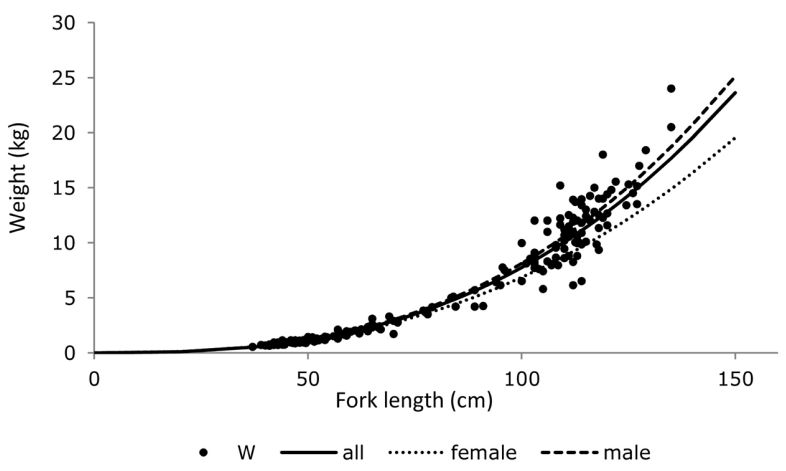

Figure 1. Weight-length relationship of Coryphaena hippurus in the coast of Oaxaca and Chiapas, Mexico, from September 2004 to September 2005 / Relación longitud-peso de Coryphaena hippurus en la costa de Oaxaca y Chiapas, México, de septiembre 2004 a septiembre 2005

Table 2. Relationship between length $(\mathrm{cm})$ and weight $(\mathbf{k g})$ of Coryphaena hippurus / Relación entre la longitud $(\mathrm{cm})$ y el peso (kg) de Coryphaena hippurus

\begin{tabular}{cccc}
\hline & All individuals & Males & Females \\
\hline $\mathrm{a}$ & $2.446 \cdot 10^{-5}$ & $2.154 \cdot 10^{-5}$ & $4.608 \cdot 10^{-5}$ \\
$\mathrm{~b}$ & 2.750 & 2.788 & 2.586 \\
$\mathrm{R}^{2}$ & 0.979 & 0.982 & 0.976 \\
$\mathrm{n}$ & 210 & 89 & 100 \\
$\mathrm{~F}$ & $9,830.21$ & $4,660.41$ & $3,906.70$
\end{tabular}

Note: $\mathrm{a}=$ intercept, $\mathrm{b}=$ slope, $\mathrm{R}^{2}=$ determination coefficient, $\mathrm{n}=$ number of individuals, $\mathrm{F}=$ test of the significance of a regression 


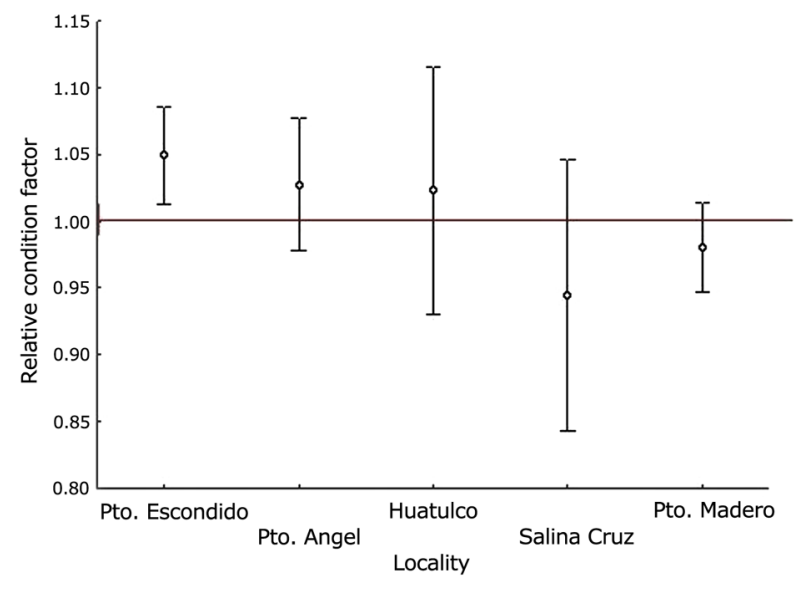

Figure 2. Relative condition factor (mean and $95 \%$ confidence interval) of Coryphaena hippurus, the horizontal line marks the expected theoretical value $\left(\mathrm{CF}_{\mathrm{r}}=\mathbf{1 . 0 0}\right)$ / Factor de condición relativo (promedio y $95 \%$ de intervalo de confianza) de Coryphaena hippurus, la línea horizontal marca el valor teórico esperado $\left(\mathrm{CF}_{r}=1,00\right)$

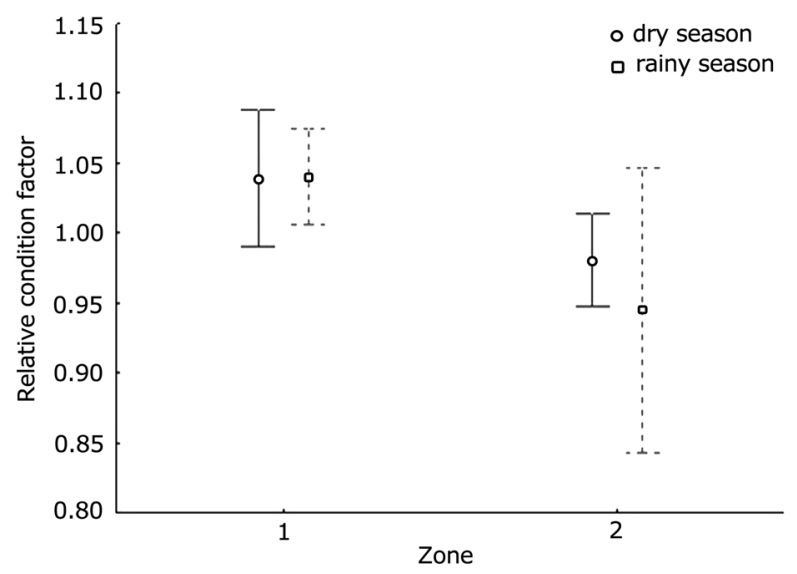

Figure 3. Relative condition factor (mean and $95 \%$ confidence interval) of Coryphaena hippurus by zone and season / Factor de condición relativo (promedio e intervalo de confianza de 95\%) de Coryphaena hippurus por zona y temporada
The anterior margin of the external aspect shows a prominent rostrum and a well-developed antirostrum, separated by the excisura major. The posterior section shows a rounded postrostrum with an excisura minor and therefore pararostrum (Fig. 4).

As the fish ages, the shape of the sagitta changes and can vary between specimens as well as between right and left sagittae in the same individual.

The antirostrum is curved and has interruptions in the form of notches or larger irregularities that increase from the middle part of the antirostrum to the pararostrum. The rostrum length tends to be rectilinear towards the postrostrum, with some indentations.

The internal aspect of the otolith is concave, a feature which increases with age; its surface is smooth and it is traversed in its entirety by the acoustic channel which increases in width from anterior (ostium region of the otolith) to posterior (cauda region).

The external aspect of the sagitta is convex, slightly thicker in the middle of the otolith than the postrostrum and pararostum. Growth rings go around the otolith nucleus and are easier to observe from the middle part of the otolith to the postrostrum and pararostrum (Figs. 5, 6 , and 7). Average width of the sagitta is 1.62 times its average length.

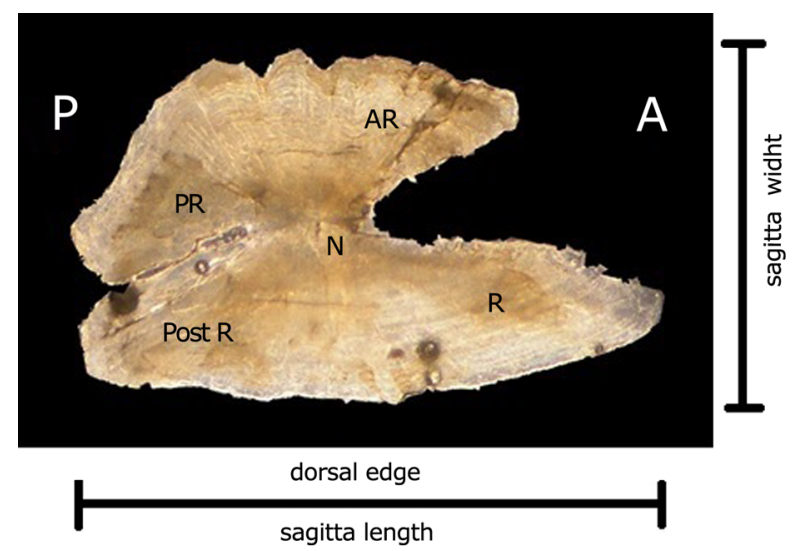

Figure 4. Internal aspect of the sagitta otolith of Coryphaena hippurus: $N=$ nucleus, $R=$ rostrum, $A R=$ antirostrum, $P R=$ pararostrum and PostR= postrostrum / Cara interna del otolito sagitta de Coryphaena hippurus: $\mathrm{N}=$ núcleo, $\mathrm{R}=$ rostrum, $\mathrm{AR}=$ antirostrum, $\mathrm{PR}=$ pararostrum y $\mathrm{Pos} \mathrm{R}=$ postrostrum 


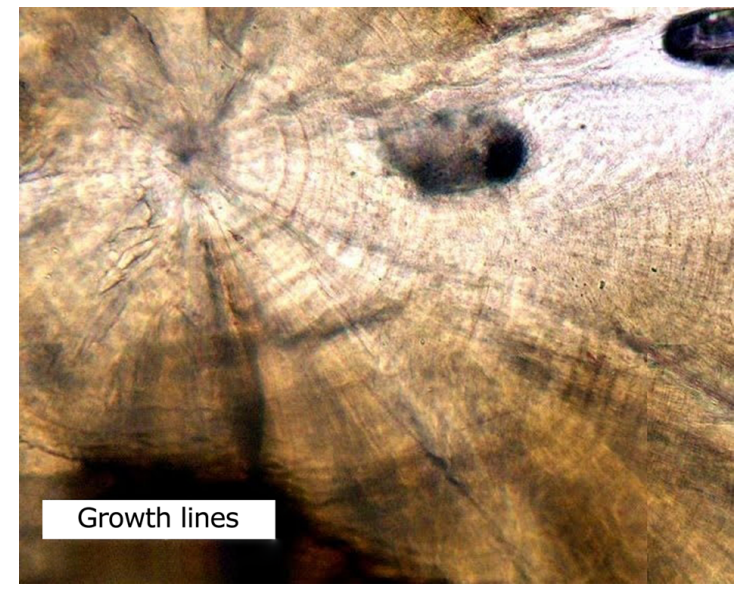

Figure 5. Nucleus and first growth increments of a sagitta otolith of Coryphaena hippurus / Núcleo y primeros incrementos de crecimiento del otolito sagitta de Coryphaena hippurus

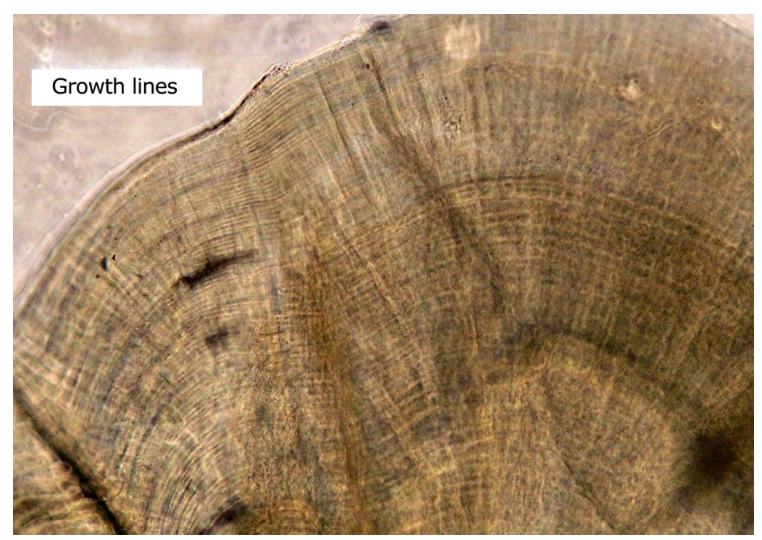

Figure 6. Growth increments on the sagitta otolith of Coryphaena hippurus / Incrementos de crecimiento en el otolito sagitta de Coryphaena hippurus

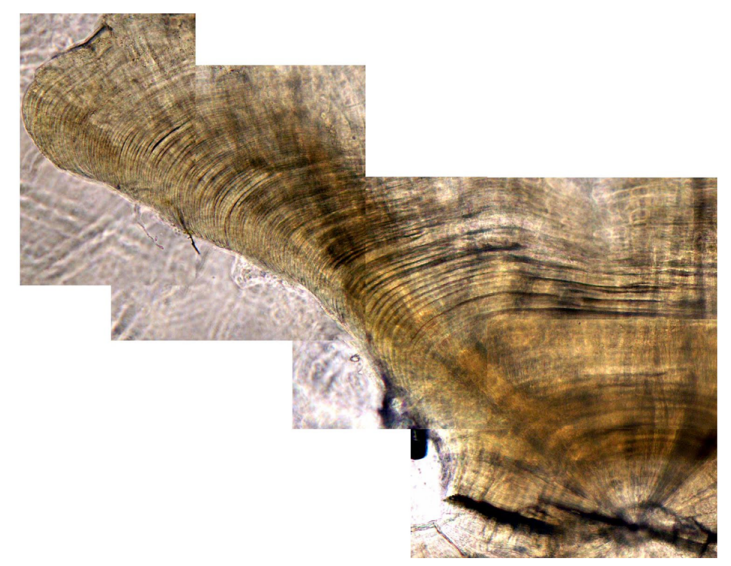

Figure 7. Daily growth increments on a sagitta otolith of Coryphaena hippurus / Incrementos de crecimiento diario en un otolito sagitta de Coryphaena hippurus

Change in rostrum length is greater in females while change in sagitta width. Otolith length is greater in males in length classes 40 to $120 \mathrm{~cm}$, is greater in females of 130 and $140 \mathrm{~cm}$. Otolith width is larger in males than in females for lengths 50 to $140 \mathrm{~cm}$ (Table 3).

Parameters for the relationship between otolith length and width for all individuals and for males and females separately are given in Table 4 . For all individuals, $b=$ $0.704, \mathrm{R}^{2}=0.701$ and $\mathrm{F}=105.343$, indicating that the sagitta tends to lengthen as the fish ages. Similar results are found for males and females.
Table 3. Length and width of the otolith of Coryphaena hippurus by class and sex / Longitud y ancho promedio del otolito de Coryphaena hippurus según clase y sexo

\begin{tabular}{ccccccccc}
\hline \multirow{3}{*}{$\begin{array}{c}\text { Classes } \\
(\mathrm{cm})\end{array}$} & $\begin{array}{c}\text { Mll } \\
\text { individuals } \\
(\mathrm{mm})\end{array}$ & $\begin{array}{c}\text { Female } \\
(\mathrm{mm})\end{array}$ & $\begin{array}{c}\text { Male } \\
(\mathrm{mm})\end{array}$ & & $\begin{array}{c}\text { All individuals } \\
(\mathrm{mm})\end{array}$ & $\begin{array}{c}\text { Female } \\
(\mathrm{mm})\end{array}$ & $\begin{array}{c}\text { Male } \\
(\mathrm{mm})\end{array}$ \\
\hline 40 & 1.77 & 1.738 & 1.890 & & 1.15 & 1.154 & 1.151 \\
50 & 2.00 & 1.967 & 2.106 & & 1.28 & 1.278 & 1.286 \\
60 & 2.21 & 2.177 & 2.300 & & 1.40 & 1.389 & 1.407 \\
70 & 2.40 & 2.372 & 2.478 & & 1.51 & 1.491 & 1.519 \\
80 & 2.58 & 2.554 & 2.643 & & 1.61 & 1.585 & 1.623 \\
90 & 2.75 & 2.727 & 2.798 & & 1.70 & 1.672 & 1.720 \\
100 & 2.91 & 2.891 & 2.945 & & 1.79 & 1.755 & 1.813 \\
110 & 3.06 & 3.048 & 3.084 & & 1.88 & 1.833 & 1.900 \\
120 & 3.21 & 3.199 & 3.216 & & 1.96 & 1.908 & 1.984 \\
130 & 3.36 & 3.345 & 3.343 & & 2.03 & 1.979 & 2.065 \\
140 & 3.49 & 3.485 & 3.465 & & 2.11 & 2.047 & 2.142 \\
\hline
\end{tabular}


Table 4. Relationship between rostrum length $(\mathrm{mm})$ and width of sagitta $(\mathbf{m m})$ of Coryphaena hippurus / Relación entre el largo del rostrum $(\mathrm{mm})$ y el ancho de la sagitta $(\mathrm{mm})$ de Coryphaena hippurus

\begin{tabular}{cccc}
\hline & All individuals & Females & Males \\
\hline $\mathrm{a}$ & 0.795 & 0.898 & 0.653 \\
$\mathrm{~b}$ & 0.704 & 0.528 & 0.923 \\
$\mathrm{R}^{2}$ & 0.701 & 0.518 & 0.846 \\
$\mathrm{n}$ & 47 & 26 & 15 \\
$\mathrm{~F}$ & 105.343 & 25.801 & 71.371 \\
\hline
\end{tabular}

Note: $a=$ intercept, $\quad b=$ slope, $R^{2}=$ determination coefficient, $\mathrm{n}=$ number of individuals, $\mathrm{F}=$ test of the significance of a regression

Table 5. Relationship between rostrum length $(\mathrm{mm})$ and width $(\mathrm{mm})$ of sagitta with individual fork length $(\mathrm{cm})$ of Coryphaena hippurus / Relación entre la longitud del rostrum $(\mathrm{mm})$ y la anchura de la sagitta $(\mathrm{mm})$, con la longitud furcal individual $(\mathrm{cm})$ de Coryphaena hippurus

\begin{tabular}{cccc}
\hline & All individuals & Females & Males \\
\hline Length & & & \\
$\mathrm{a}$ & 0.239 & 0.224 & 0.317 \\
$\mathrm{~b}$ & 0.543 & 0.555 & 0.484 \\
$\mathrm{R}^{2}$ & 0.736 & 0.607 & 0.799 \\
$\mathrm{n}$ & 47 & 26 & 15 \\
$\mathrm{~F}$ & 125.584 & 37.050 & 51.689 \\
Width & & & \\
$\mathrm{a}$ & 0.193 & 0.213 & 0.185 \\
$\mathrm{~b}$ & 0.484 & 0.458 & 0.496 \\
$\mathrm{R}^{2}$ & 0.828 & 0.766 & 0.833 \\
$\mathrm{n}$ & 47 & 26 & 15 \\
$\mathrm{~F}$ & 216.160 & 78.497 & 65.001 \\
\hline
\end{tabular}

Note: $\mathrm{a}=$ intercept, $\mathrm{b}=$ slope, $\mathrm{R}^{2}=$ determination coefficient, $n=$ number of individuals, $F=$ test of the significance of a regression

These results show that the growth of sagitta is eccentric to the nucleus. This is a characteristic, which increases with the age of the fish, i.e., the postrostrum grows more than the rostrum and the antirostrum. The dorsal edge grows more than the ventral edge, and a larger amount of material accumulates on the inner than on the external aspect.

The relationship between fish length (FL) and otolith length and width is given in Table 5. The allometric index (b) relating fish length to rostrum length is 0.543 for the species, $b=0.555$ for females and $b=0.484$ for males. The allometric index (b) relating fish length to otolith width is 0.484 for the species, $b=0.496$ for males, and $b=0.458$ for females. The ANOVA (F) shows a strong correlation between otolith length-width and fish length and therefore growth of the otoliths adequate to describe the growth of Dolphinfish. Values of allometric growth rates are below one, due to the difficulty of relating very small structures (in millimeters) with values of total fish length, expressed in centimeters.

\section{Age DETERmination - DAILY INCREMENTS}

The presence of daily increments, easy to discern in Dolphinfish otoliths provides a method remarkably accurate and precise to estimate the age in fish (Campana \& Thorrold 2001).

Counting daily increments in polished otoliths was possible in 54 fish (32.7\% of total), 16 males and 32 females, and 6 cases undetermined or juvenile.

Due to the complex shape of the otolith, most of the readings were made in the pararostrum section (PR), where the growth marks were clearer. In cases where the sequence was not complete in the PR, the counting started in another part near the nucleus and followed along a section where the increments were clear. The spacing of daily growth varied in different sections of the pararostrum. Near the nucleus the distance between the daily rings is relatively wide and as you move toward the distal region the distance becomes smaller (Figs. 5, 6 and 7).

In bigger sized otoliths (> $2.7 \mathrm{~mm}$ ), daily growth increments in some sections were found so close to each other that identifying a daily ring became difficult and it was hard to separate the lines, and the age readings can be uncertain for these larger fish.

\section{Average length of EaCh AGe}

Five age groups were determined based on daily age readings obtained in the otolith analysis. The fork length for each age group was calculated based on observed values as well as calculated values using de von Bertalanffy growth equation (Table 6 and Fig. 8).

In the first 2 age groups the standard deviation for age was low, which indicates that the precision was higher, due probably to a larger sample size (Table 6). As fish grow, the variability also increases. 
Table 6. Relationship between age and length for 5 age groups of Coryphaena hippurus / Relación entre la edad y la longitud de 5 grupos de edad de Coryphaena hippurus

\begin{tabular}{cccccc}
\hline $\begin{array}{c}\text { Age } \\
\text { groups }\end{array}$ & $\begin{array}{c}\text { Age } \\
\text { (years) }\end{array}$ & $\begin{array}{c}\text { Fork length } \\
(\mathrm{cm})\end{array}$ & $\begin{array}{c}\text { Calculated } \\
\text { FL }(\mathrm{cm})^{*}\end{array}$ & $\mathrm{~N}$ & $\begin{array}{c}\text { Standard } \\
\text { deviation }\end{array}$ \\
\hline 1 & 0.31 & 48.50 & 43.98 & 23 & 3.14 \\
2 & 0.44 & 53.85 & 64.21 & 24 & 6.75 \\
3 & 0.58 & 84.63 & 82.46 & 3 & 29.90 \\
4 & 0.71 & 107.5 & 98.77 & 2 & 47.37 \\
5 & 0.84 & 108.5 & 113.56 & 2 & 4.60 \\
\hline
\end{tabular}

* calculated with von Bertalanffy's growth parameters in Table 7

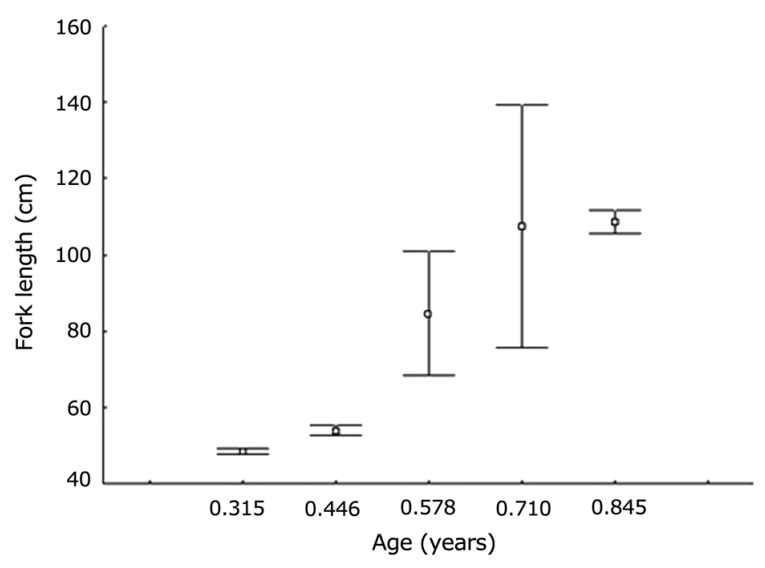

Figure 8. Relationship between age and fork length (mean and standard error) of Coryphaena hippurus / Relación entre la edad y la longitud furcal (promedio y error estándar) de Coryphaena hippurus

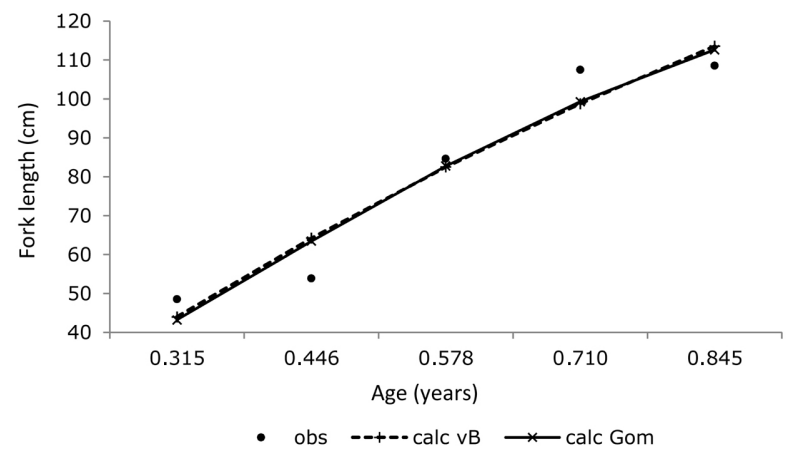

Figure 9. Growth curve of Coryphaena hippurus, showing the observed (obs) and calculated values based on von Bertalanffy maximum likelihood (calc vB) and Gomperz methods (calc Gom) / Curva de crecimiento de Coryphaena hippurus, se muestran los valores observados (obs) y los calculados con la ecuación de von Bertalanffy por el método de máxima verosimilitud (calc vB) y el modelo de Gompertz (calc Gom)
The parameters of the growth equation of von Bertalanffy that best fit the observed data, based on the lowest value for the quadratic sum of differences (SD), were those obtained with the likelihood method. The calculated curve (Fig. 9) of $C$. hippurus was: $\mathrm{L}=231.65$ $\mathrm{cm}, \mathrm{K}=0.874$, and $\mathrm{t}_{\mathrm{o}}=0.074$, which gave a value of $\Phi^{\prime}=$ 4.67 .

The observed values fell within the first part of the curve of the predicted values, with a maximum age of 4 years selected based on information from Beardsley (1967) (Fig. 10).

The Gompertz growth model, gave similar results (Table 7, Fig. 9). Gompertz equation considers that the growth rate $(\mathrm{G})$ for this species is de 3.04 , but the growth rate is not constant, and decreases at a rate $\mathrm{g}=2.89$.

Using the maximum likelihood equation, theoretical lengths were calculated for each age group (Table 6).

\section{GROWTH IN WEIGHT}

Values of weight for each age are observed in Table 8 , and the von Bertalanffy growth equation in weight is:

$$
\mathrm{W}_{\infty}=77.926\left[1-\mathrm{e}^{-0.87(\mathrm{t}-0.074)}\right]^{2.75}
$$

\section{LONGEVITY}

C. hippurus reached $95 \%$ of its infinite length $\mathrm{L}_{\infty}$ in 3.502 years.

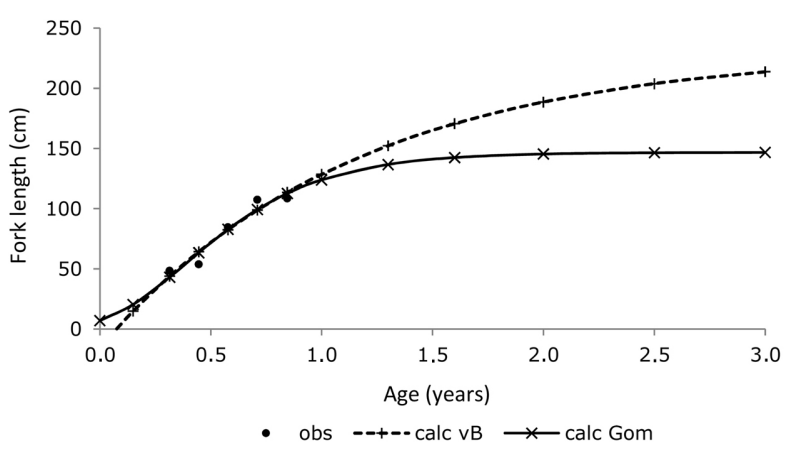

Figure 10. Growth curve of Coryphaena hippurus, extended out to a maximum age of 3 years and showing the expected values of the von Bertalanffy maximum likelihood model (calc vB) and Gompertz model (calc Gom) / Curva de crecimiento de Coryphaena hippurus, extrapolado a la edad de 3 años y que muestra los valores esperados del modelo de máxima verosimilitud de von Bertalanffy (calc vB) y el modelo de Gompertz (calc Gom) 
Table 7. Growth parameters of the von Bertalanffy equation by different methods / Parámetros de crecimiento de la ecuación de von Bertalanffy estimado por diferentes métodos

\begin{tabular}{ccccc}
\hline Estimation method & $\mathrm{L}_{\infty}$ & $\mathrm{K}$ & $\mathrm{t}_{0}$ & $\mathrm{SD}^{2}$ \\
\hline $\begin{array}{c}\text { Ford-Walford and } \\
\text { Gulland and Holt }\end{array}$ & 148.78 & 0.220 & -0.840 & 342.57 \\
Leven-Maquardt & 231.56 & 0.875 & 0.070 & 235.64 \\
Maximum likelihood & 231.65 & 0.874 & 0.074 & 234.27 \\
& $\mathrm{~L}_{0}$ & $\mathrm{G}$ & $\mathrm{g}$ & $\mathrm{SD}^{2}$ \\
Gompertz & 7.02 & 3.04 & 2.89 & 206.19 \\
\hline
\end{tabular}

Note: $\mathrm{L}_{\infty}=$ asymptotic length $(\mathrm{cm}), \mathrm{K}=$ growth rate index, and $\mathrm{t}_{0}=$ theoretic length at age $0, \mathrm{SD}^{2}=$ sum of squares

\section{Discussion}

C. hippurus increase their size at higher rates than their weight. Their shape is fusiform which allows them to move quickly through the water, aiding in migration and feeding. The weight-length relationship for Dolphinfish found in this study is similar to that reported by others for this species (Lasso \& Zapata 1999, Massutí et al. 1999, Thompson 1999, Rivera \& Appeldoorn 2000, ZúñigaFlores 2002, Schwenke \& Buckel 2008) (Table 9). In general, the slope values for the weight-length relationships are under 3 , indicating negative allometric growth (i.e., rate of growth in length is greater than in weight). However, Castro et al. (1999) from Islas Canarias, Madrid \& Beltrán (2001) from Los Cabos reported positive allometric growth indexes, and Alejo-Plata et al. (2011) also reported a positive allometric growth rate in males, in females it was a negative allometric index (Table 9). Differences in the allometric index values reported for different regions may be associated with the availability of food and/or Dolphinfish population structure (Madrid \& Beltrán 2001). Differences in weight-length relationship between sexes were found in this study as in others (Lasso \& Zapata 1999, Massutí et al. 1999, Madrid \& Beltrán 2001, Zúñiga-Flores 2002, Schwenke \& Buckel 2008). Males are typically heavier than females due to the added weight of the crest bone on the head of the males (Rose \& Hassler 1968). Alejo-Plata et al. (2011) reported that the weight of males increase from the first year on compared to females, when the sexual dimorphism and the bony crest increases its size. In addition, males had a relative higher condition factor than females.
Table 8. Observed and calculated values of fork length $(\mathrm{cm})$ and weight (kg) for each age group (years) of Coryphaena hippurus / Valores observados y calculados de la longitud furcal $(\mathrm{cm})$ y del peso $(\mathrm{kg})$ de cada grupo de edad (años) de Coryphaena hippurus

\begin{tabular}{cccccc}
\hline $\begin{array}{c}\text { Age } \\
\text { (years) }\end{array}$ & $\begin{array}{c}\text { FL } \\
(\mathrm{cm})\end{array}$ & $\begin{array}{c}\mathrm{W}^{*} \\
(\mathrm{~kg})\end{array}$ & $\begin{array}{c}\text { Growth } \\
\text { index }\end{array}$ & $\begin{array}{c}\mathrm{W}^{* *} \\
(\mathrm{~kg})\end{array}$ & $\begin{array}{c}\text { Growth } \\
\text { index }\end{array}$ \\
\hline 0.31 & 43.980 & 0.809 & & 0.759 & \\
0.44 & 64.210 & 2.291 & 1.482 & 2.187 & 1.428 \\
0.58 & 82.460 & 4.559 & 2.267 & 4.555 & 2.368 \\
0.71 & 98.770 & 7.488 & 2.930 & 7.407 & 2.852 \\
0.84 & 113.560 & 10.991 & 3.503 & 10.741 & 3.334 \\
\hline
\end{tabular}

* weight-length relationship

** von Bertalanffy growth equation

The highest values of relative condition factor found in the zone I may be related to 2 possible explanations: 1) reproduction, and 2) food availability. Changes in the condition factor of fish may indicate gonad maturation or changes in the intensity of feeding (Weatherly \& Gill 1987, Wootton 1991, Salgado-Ugarte et al. 2005). The fact that the relative condition factor in zone I is higher and does not show differences per seasons, could indicate that reproduction occurs more than once a year, however, if this were not so, then the zone could be a feeding area. Alejo-Plata et al. (2011) report several massive spawning of Dolphinfish in the same study area as the present analysis, noting September to November and February to March as the seasons when the gonadosomatic index reaches its highest values, and May as the period when this index is the lowest.

Only $32 \%$ of the otoliths could be read, due to the difficulties in the method. During their processing, some samples broke, making it impossible to read, or some had bubbles under or on top of a part of the otolith, an effect of pouring the resin on the otolith, making the reading process difficult. Also, during polishing, some samples were over polished, destroying part of the otolith and making it impossible to read. In some cases the otolith presented an opaque section which did not allow the reading. The work was complex, because a section of the otolith containing all the increases in a linear sequence had to be found. In some cases readings had to follow the rings in several sections of the otolith, to obtain the complete sequence. 
Table 9. Weight-length relationship equations for $C$. hippurus from the literature and this study / Ecuación de la relación longitud-peso de $C$. hippurus de la literatura y este studio

\begin{tabular}{llcccc}
\hline \multicolumn{1}{c}{ Authors } & \multicolumn{1}{c}{ Locality } & $\mathrm{n}$ & $\begin{array}{c}\text { Length range } \\
\mathrm{FL}(\mathrm{cm})\end{array}$ & Weight-length relationship & $\mathrm{R}^{2}$ \\
\hline Castro et al. (1999) & Islas Canarias & $\mathrm{N} / \mathrm{D}$ & $76-103$ & $\mathrm{~W}=\left(9.50 \cdot 10^{-4}\right) \cdot \mathrm{FL}^{3.53}$ & 0.92 \\
Lasso \& Zapata (1999) & Colombia and Panamá & 147 & $29-197$ & $\mathrm{~W}=\left(2.24 \cdot 10^{-2}\right) \cdot \mathrm{FL}^{2.78}$ & 0.90 \\
Massutí et al. (1999) & Mediterranean coast & 350 & $14-124$ & $\mathrm{~W}=\left(1.13 \cdot 10^{-2}\right) \cdot \mathrm{FL}^{2.96}$ & 0.99 \\
Thompson (1999) & Northwest Atlantic & 32,215 & $\mathrm{~N} / \mathrm{D}$ & $\mathrm{W}=\left(2.98 \cdot 10^{-5}\right) \cdot \mathrm{FL}^{2.71}$ & 0.97 \\
Rivera \& Appledoorn (2000) & Puerto Rico & 170 & $38-148$ & $\mathrm{~W}=\left(3.80 \cdot 10^{-5}\right) \cdot \mathrm{FL}^{2.78}$ & 0.96 \\
Madrid \& Beltrán (2001) & Los Cabos, Mex. & 1,065 & $47-192$ & $\mathrm{~W}=(0.00007) \cdot \mathrm{FL}^{3.03}$ & 0.94 \\
Zúñiga-Flores (2002) & Mazatlan, Mex. & 800 & $38-164$ & $\mathrm{M}: \mathrm{W}=(0.000012) \cdot \mathrm{FL}^{2.90}$ & 0.97 \\
& Nayarit, Mex. & 338 & $40-140$ & $\mathrm{~F}: \mathrm{W}=(0.000034) \cdot \mathrm{FL}^{2.64}$ & 0.95 \\
& Mazatlan, Mex. & 1,409 & $40-129$ & $\mathrm{~W}=(0.0000002) \cdot \mathrm{FL}^{2.71}$ & 0.94 \\
& & 274 & $31-145$ & $\mathrm{M}: \mathrm{W}=\left(2.25 \cdot 10^{-8}\right) \cdot \mathrm{FL}^{2.87}$ & 0.89 \\
Schwenke \& Buckel (2008) & North Carolina, USA & 218 & $20-143$ & $\mathrm{~F}: \mathrm{W}=\left(9.42 \cdot 10^{-8}\right) \cdot \mathrm{FL}^{2.64}$ & 0.92 \\
Alejo-Plata et al. (2011) & Gulf of Tehuantepec, Mex. & 7,371 & $20-140$ & $\mathrm{M}: \mathrm{W}=\left(4 \cdot 10^{-6}\right) \cdot \mathrm{FL}^{3.144}$ & \\
Present study & Mexican South Pacific & 210 & $37-135$ & $\mathrm{~W}=\left(2.45 \cdot 10^{-5}\right) \cdot \mathrm{FL}^{2.75}$ & 0.97 \\
\hline
\end{tabular}

Note: $\mathrm{W}=$ weight, $\mathrm{FL}=$ fork length, $\mathrm{n}=$ number of individuals, $\mathrm{N} / \mathrm{D}=$ no data, $\mathrm{R}^{2}=$ determination coefficient, $\mathrm{M}=$ males, $\mathrm{F}=$ females

Table 10. Parameters of the equation of von Bertalanffy for C. hippurus from the literature and this study / Parámetros de la ecuación de von Bertalanffy registrados para C. hippurus de la literatura y este estudio

\begin{tabular}{|c|c|c|c|c|c|c|c|}
\hline Locality & $\mathrm{L}_{\infty}$ & K & $\mathrm{t}_{0}$ & $\mathrm{n}$ & $\Phi^{\prime} *$ & Method & Reference \\
\hline Florida & 165.00 & 0.680 & 0.155 & 511 & 4.27 & Scales & Beardsley (1967) \\
\hline North Carolina & 159.70 & 0.400 & -0.964 & 738 & 4.01 & Scales & Rose \& Hassler (1968) \\
\hline Barbados & 120.80 & 3.490 & 0.055 & - & 4.71 & Otoliths & Oxenford \& Hunte (1983) \\
\hline St. Lucia & 236.10 & 0.530 & -0.173 & & 4.47 & & Murray (1985) \\
\hline Hawaii & $\mathrm{N} / \mathrm{C}$ & $\mathrm{N} / \mathrm{C}$ & $\mathrm{N} / \mathrm{C}$ & 10 & & Otoliths & Uchiyama et al. (1986) \\
\hline \multirow[t]{2}{*}{ Hawaii } & 189.93 & 1.187 & 0.079 & 10 males & 4.63 & Captivity & \\
\hline & 153.27 & 1.411 & 0.073 & 9 females & 4.52 & & \\
\hline Gulf of Mexico & 194.00 & 1.120 & 0.033 & & 4.62 & Otoliths & Bentivoglio (1988) \\
\hline Ecuador & 195.00 & 0.410 & & - & 4.19 & $\begin{array}{l}\text { Length } \\
\text { frequency }\end{array}$ & $\begin{array}{c}\text { Patterson \& Martínez } \\
\text { (1991) }\end{array}$ \\
\hline Puerto Rico & 145.70 & 2.190 & -0.046 & & 4.67 & Otoliths & Rivera-Betancourt (1994) \\
\hline Panama and Colombia & 194.00 & 0.910 & 0.104 & 3477 & 4.53 & $\begin{array}{l}\text { Length } \\
\text { frequency }\end{array}$ & Lasso \& Zapata (1999) \\
\hline Mediterranean & 102.40 & 1.900 & 0.023 & 212 & 4.29 & Otoliths & Massutí et al.(1999) \\
\hline Puerto Rico & 145.70 & 2.190 & -0.046 & 121 & 4.67 & Otoliths & Rivera \& Appeldorn (2000) \\
\hline North Carolina & 129.90 & 1.080 & -0.086 & 126 & 4.26 & $\begin{array}{l}\text { Otoliths } \\
\text { and scales }\end{array}$ & Schwenke \& Bucler (2008) \\
\hline \multirow[t]{2}{*}{ Gulf of Tehuantepec } & 125.82 & 0.996 & -0.037 & 136 females & 4.20 & Scales & Alejo-Plata et al. (2011) \\
\hline & 126.29 & 1.000 & -0.039 & 105 males & 4.20 & Scales & \\
\hline Mexican South Pacific & 231.65 & 0.874 & 0.074 & 54 & 4.67 & Otoliths & This study \\
\hline
\end{tabular}

Note: $\mathrm{L}_{\infty}=$ asymptotic length, $\mathrm{K}=$ growth parameter, $\mathrm{t}_{0}=$ hypothetic age when length is $0, \mathrm{n}=$ number of data, $\Phi^{\prime}=$ phi prima, growth evaluation index (Pauly, 1979), ${ }^{*}$ calculated by authors, N/C = not calculated 
Studies based on the analysis of daily growth increments in sagittae are scarce and this is the first to carry out this study in the coast of Oaxaca and Chiapas, Mexico. This method is very precise in the daily count during the first stages of growth, but can be confusing in older individuals. It is very important to have different methods of evaluation, such as scale reading (Schwenke \& Bukel 2008, Zúñiga-Flores 2009, Alejo-Plata et al. 2011), and vertebra analysis (Morales-Nin et al. 1999), to compare and finally understand how this species grows.

Age determination in the 4 largest Dolphinfish (FL > 100 $\mathrm{cm}$ ) were likely under aged, as growth increments were very close to each other. This is consistent with reports by Massutí et al. (1999) and Schwenke \& Buckel (2008), who mention that daily ages calculated in adult fish $(>60$ and $>65 \mathrm{~cm}$ respectively) are underestimated. This is because there is a progressive decrease in the amplitude of the daily growth increase as the fish grows and ages, to the extent that it is no longer possible to see a greater number of increments of growth because growth bands overlap. This is similar to the progressive decrease in the rate of growth in length in which there comes a time when the length is asymptotic (Gallardo-Cabello et al. 2007).

Daily growth marks were distinguished in otoliths, but not monthly or annual periodic marks, which coincide with findings by Massutí et al. (1999), and Schwenke \& Buckel (2008). Daily growth increments are caused by differences in the availability of food during the day and night. Zooplankton makes nictameral migrations so they are more available to fish in the surface layers at dawn. Daily growth increments correspond to changes in diurnal-nocturnal metabolism; darker bands are formed when there is greater availability of food and correspond to periods of rapid growth. The lighter bands correspond to periods of slow growth, with reduced availability of food (Gallardo-Cabello et al. 2010).

For those samples that could be aged, the coefficient of variation in readings was low and a good precision index $(\mathrm{P})$; these values were within the range reported for other species (Chang 1982, Kimura \& Lyons 1991).

The standard deviation of the first 2 age groups was lower than that of the last age, which means that the accuracy was higher for the youngest age groups. Schwenke \& Buckel (2008) mentioned that ages calculated with sagittae in adults of $C$. hippurus are underestimated, as well as in our study. The lower values of $\mathrm{L}_{\infty}$ obtained for this species are those reported by Massutí et al. (1999) in the Mediterranean: $\mathrm{L}_{\infty}=102.4 \mathrm{~cm}$, Oxenford \& Hunte
(1983) in Barbados, $\mathrm{L}_{\infty}=120.8 \mathrm{~cm}$, Alejo-Plata et al. (2011) in the Gulf of Tehuantepec, México $\mathrm{L}_{\infty}=125.82 \mathrm{~cm}$ in females and $\mathrm{L}_{\infty}=126.29 \mathrm{~cm}$ in males, and Schwenke \& Buckel (2008) in North Carolina $\mathrm{L}_{\infty}=129.9 \mathrm{~cm}$. Values of the asymptotic length obtained by Massutí et al. (1999), Schewenke \& Buckel (2008), and Alejo-Plata et al. (2011) were considered underestimated by the same authors. The first two authors suggest that this underestimation is due to the count of daily growth increments, phenomena that was not observed in the present study, which obtained a $\mathrm{L}_{\infty}=231.5 \mathrm{~cm}$. In the case of the study of AlejoPlata et al. (2011), authors considered that the underestimation found in $\mathrm{L}_{\infty}$ of their study was due to the small number of fish scales that were larger than $120 \mathrm{~cm}$ of fork length, although the value of $\mathrm{L}_{\infty}$ reported is representative for the Dolphinfish obtained by the coastal small scale fishery. We consider that the study of scales and otoliths can provide good results to identify growth rings, provided samples can be obtained without bias, that is, that it includes most length classes of the species. Therefore organisms obtained from the commercial fishery as from tournaments (where bigger sizes are fished) should be included.

Comparatively, parameter values of $\mathrm{K}$ and $\mathrm{L}_{\infty}$ in the von Bertalanffy growth equation is within the range of values reported for the species in other locations (Table 10). Results of parameters depend mostly of the sample taken, therefore it is important to have individuals of all ages, which is not very easy to obtain. In the case of coastal captures, individuals are smaller sizes than those captured in high seas by larger vessels.

Values of K reported by Beardsley (1967) for the coast of Florida, Lasso \& Zapata (1999) for the coast of Panama and Colombia, and Alejo-Plata et al. (2011) for the Gulf of Tehuantepec are the closest to those reported in this study. Also, the value reported by Murray (1985) in Santa Lucia $\left(\mathrm{L}_{\infty}=236.1 \mathrm{~cm}\right)$ is similar to the one reported here $\left(\mathrm{L}_{\infty}=231.65 \mathrm{~cm}\right)$. Other values of the asymptotic length approaching the one found in this study are those reported by Uchiyama et al. (1986) of $\mathrm{L}_{\infty}=189.93 \mathrm{~cm}$ in males in the coast of Hawaii; $\mathrm{L}_{\infty}=194 \mathrm{~cm}$ reported by Bentivoglio (1988) in the Gulf of Mexico; $\mathrm{L}_{\infty}=195 \mathrm{~cm}$ found by Patterson \& Martínez (1991) in Ecuador; and $\mathrm{L}_{\infty}=194$ cm reported by Lasso \& Zapata (1999) in Panama and Colombia. Lower values of $\mathrm{L}_{\infty}$ have been found by other authors because no large sized organisms were sampled, which could indicate that the asymptotic length was underestimated (Oxenford \& Hunte 1983, Massutí et al. 1999, Alejo-Plata et al. 2011). Methods are very sensible 
to the samples evaluated. In our study we had large individuals (141 cm FL), therefore the asymptotic parameter is high, but does not mean it is overestimated.

The value obtained for $\Phi^{\prime}$ in this study (4.67) was higher than that of Massutí et al. (1999) and Schwenke \& Buckel (2008), who obtained 4.29 and 4.26, respectively, in studies of otoliths from juvenile and scales in adult Dolphinfish. However, the value obtained is close to that reported by Oxenford \& Hunte (1983) $\Phi^{\prime}=4.71$ and Bentivoglio (1988) $\Phi^{\prime}=4.62$. Schwenke \& Buckel (2008), and Rivera \& Appeldoorn (2000), who studied growth based solely on otoliths, obtained values of $\Phi^{\prime}=6.26$ and $\Phi^{\prime}=6.67$. From parameters reported by Torres-Alfaro (1996) a value of $\Phi^{\prime}=3.93$ was calculated, this study was with scales. The difference in the value of $\Phi^{\prime}$ obtained in studies conducted only in otoliths compared to those using scales is probably due to the underestimation of age in adult fish in this fast growing species. However $\Phi^{\prime}$ values obtained for the species in different localities are the same (Rivera-Betancourt 1994, Rivera \& Appeldorn 2000).

The maximum age reported for the species is 4 years, according to Beardsley (1967).

The growth of $C$. hippurus is accelerated in the first year of its life. C. hippurus are prey to other pelagic species, and are affected by their pressure; therefore, as a survival strategy, their length increases very fast. This is consistent with that reported by Nakamura (1985) for pelagic billfish.

Longevity found in the present study was of 3.502 years, similar to that reported by Schwenke \& Buckel (2008) of 3 years. Alejo-Plata et al. (2011) indicated that C. hippurus can reach 5 years of age, but other authors calculated only one year of age (Beardsley 1967, Bentivoglio 1988, Rivera \& Appeldorn 1994).

According to Barcelata-Ortiz et al. (1990), the first maturity length of $C$. hippurus in Mazatlan is $44 \mathrm{~cm}$ fork length for both sexes. This length corresponds to less than a year of age. The same is mentioned by Beardsley (1967) for organisms in Florida, USA. According to Barcelata-Ortiz et al. (1990) and to the estimation of growth parameters in the present study using the likelihood method, Dolphinfish would reach their first maturity at 4 months. Oxenford (1999) mentioned that the age of first maturity varies according to locality.

The Gompertz model is used mainly to calculate growth in weight, although Ricker (1975) mentions that it is valid to use this model to estimate growth in size. The growth curve of this model has a sigmoid shape and a lower and upper asymptote, the lower asymptote is not important in growth, so only part of the graph is used. Ricker (1975) noted that the Gompertz model adequately describes the growth in the first years of life, this could be the main reason why this model was the best fit to the growth period studied, because the growth in the early stages of life presents a sigmoid-type growth.

The growth model of Gompertz considers that the growth rate of a fish diminishes throughout its life. If the instantaneous rate of decrease in the growth rate is constant, it leads to the curve suggested by Gompertz (1825) (Salgado-Ugarte et al. 2005).

The model of Gompertz presented a better fit to the observed values $\left(\mathrm{SD}^{2}=206.19\right)$ than the von Bertalanffy model during the first weeks or months of life.

The von Bertalanffy maximum likelihood model is used to describe growth during the whole life, but in this study there were no organisms close to the calculated asymptotic length.

In conclusion, growth in Dolphinfish from Oaxaca and Chiapas regions of Mexico was examined during its first year of life, as well as the growth and longevity estimates based on VBG and Gompertz models, which compare well to other studies but are considered preliminary due to a lack of samples older than 1 year. Weight-length relationship showed a negative allometric growth coefficient of 2.75 for the species, 2.58 in females and 2.79 in males. Males showed a higher relative condition factor $(\mathrm{CFr}=1.01)$ than females $(\mathrm{CFr}=0.96)$.

Sagittae lengthen as the fish grows older. Its growth is eccentric to the nucleus. Daily growth increments are discerned in the sagittae, and are more easily counted in the pararostrum. Values of the growth constants of von Bertalanffy equation were $\mathrm{L}_{\infty}=231.50 \mathrm{~cm}, \mathrm{~W}_{\infty}=77.92 \mathrm{~kg}$, $\mathrm{K}=0.874$, and $\mathrm{t}_{0}=0.074$. The best adjustment between the observed and calculated values was obtained with the Gompertz growth curve. The calculated value of Phi prima was $\Phi^{\prime}=4.67$. Longevity was 3.5 years.

\section{ACKNOWLEDGMENTS}

SAGARPA-CONACYT for funding the Project 'Caracterización biológica y pesquera del Dorado (Coryphaena hippurus) en el Pacífico Sur de México', Clave SAGARPA-2003-C01-225. Genoveva Ladrón de Guevara and Pablo Torres helped improve the study. Also, 
authors thank fishermen in the coast of Oaxaca for their help in obtaining the samples used in this study. We also thank the anonymous reviewers who made a thorough correction of our manuscript and improved it.

\section{LITERATURE CITED}

Alejo-Plata C, JL Gómez-Márquez \& IH Salgado-Ugarte. 2011. Edad y crecimiento del Dorado Coryphaena hippurus, en el Golfo de Tehuantepec, México. Revista de Biología Marina y Oceanografía 46(2): 125-134.

Barcelata-Ortiz M, J de la O-Girón \& L Gómez-Márquez. 1990. Aspectos reproductivos de las especies: Pez Vela Istiophorus platypterus y Dorado Coryphaena hippurus capturados en las costas de Mazatlán, Sinaloa en 1988. Tesis, Universidad Autónoma de Sinaloa, México, 56 pp.

Beardsley GL. 1967. Age, growth and reproduction of the dolphin, Coryphaena hippurus in the Straits of Florida. Copeia 2: 441-451.

Bentivoglio AA. 1988. Investigations into the growth, maturity, mortality rates and occurrence of the dolphin (Coryphaena hippurus, Linnaeus) in the Gulf of Mexico. Theses M. Sc., University College of North Wales, Bangor, $37 \mathrm{pp}$.

Brothers EB. 1987. Methodological approaches to the examination of otoliths in aging studies. In: Summerfelt RC \& GE Hall (eds). Age and growth of fish, pp. 319-330. Iowa State University Press, Ames.

Campana SE \& SR Thorrold. 2001. Otoliths, increments and elements: keys to a comprehensive understanding of fish populations? Canadian Journal of Fisheries and Aquatic Sciences 58: 30-38.

Cannizzaro L, F D’Andrea, A Potoschi \& M Scalisi. 1999. Economic aspects of the fishing of Dolphin-fish off Sicily. Scientia Marina 63(3-4): 459-464.

Castro JJ, JA Santiago, V Hernández \& C Pla. 1999. Growth and reproduction of the dolphin fish (Coryphaena equiselis and Coryphaena hippurus) in the Canary Islands, CentralEast Atlantic. Scientia Marina 63(3-4): 317-325.

Chang WB. 1982. A statistical method for evaluating the reproducibility of age determination. Canadian Journal of Fisheries and Aquatic Sciences 39: 1208-1210.

Díaz-Jaimes P, M Uribe-Alcocer, S Ortega-García \& JD Durand. 2006. Spatial and temporal mitochondrial DNA genetic homogeneity of Dolphinfish populations (Coryphaena hippurus) in the eastern central Pacific. Fisheries Research 80: 333-338.

Dobson AJ. 2002. An introduction to generalized linear models, 225 pp. Chapman and Hall, Boca Raton.

DOF. 2004. Carta Nacional Pesquera, 439 pp. Diario Oficial de la Federación, Secretaría de Agricultura, Ganadería, Desarrollo Rural, Pesca y Alimentación, México.

Espino-Barr E, M Cruz-Romero \& A García-Boa. 2003. Peces marinos con valor comercial de la costa de Colima, México, 125 pp. CONABIO INP, México.
Espino-Barr E, M Gallardo-Cabello, EG Cabral Solís, A Garcia-Boa \& M Puente-Gómez. 2008. Growth of the Pacific jack Caranx caninus (Pisces: Carangidae) from the coast of Colima, México. Revista de Biología Tropical 56(1): 171-179.

FAO. 2015. Fisheries and Aquaculture fact sheets. Food and Agriculture Organization of the United Nations for a world without hunger. <http://www.fao.org/fishery/species/3130/ en>

Fischer W, F Krupp, W Schneides, C Sommer, KE Carpenter \& UH Niem. 1995. Guía FAO para la identificación de especies para los fines de la pesca. Pacífico Centro Oriental. Vertebrados Vols. 2 y 3: 644-1813. FAO, Roma.

Ford E. 1933. An account of the herring investigations conducted at Plymouth during the years from 1924 to 1933. Journal of the Marine Biological Association of the United Kingdom 19: 305-384

Gallardo-Cabello M, E Espino-Barr, A Garcia-Boa, EG Cabral-Solís \& M Puente-Gómez. 2007. Study of the growth of the green jack Caranx caballus Günther 1868, in the coast of Colima, México. Journal of Fisheries and Aquatic Science 2(2): 131-139.

Gallardo-Cabello M, M Sarabia-Méndez, E Espino-Barr \& V Anislado-Tolentino. 2010. Biological aspects of Lutjanus peru in Bufadero Bay, Michoacán, México: growth, reproduction and condition factors. Revista de Biología Marina y Oceanografía 45(2): 205-215.

García-Nava H. 2003. Presencia de Vibrio cholerae en la zona costera Bahías de Puerto Ángel-Barra de Tonameca. Tesis, Universidad del Mar, Puerto Ángel. Oaxaca, México, 46 pp.

Gompertz B. 1825. On the nature of the function expressive of the law of human mortality, and on a new mode of determining life contingences. Philosophical Transactions of the Royal Society of London 115: 513-585.

Gulland JA \& SJ Holt. 1959. Estimation of growth parameters for data at unequal time intervals. Journal du Conseil CIEM 25(1): 47-49.

Harvey JT, TR Loughlin, MA Perez \& DS Oxman. 2000. Relationship between fish size and otolith length for 63 species of fishes from the Eastern North Pacific Ocean. NOAA Technical Report NMFS 150: 1-38.

Kimura DK \& JJ Lyons. 1991. Between-Reader and variability in the age-determination Process. Fishery Bulletin 84: 53-60.

Kirkwood GP. 1983. Estimation of von Bertalanffy growth curve parameters using both length increment and age-length data. Canadian Journal of Fisheries and Aquatic Sciences 40: 1405-1411.

Kojima S. 1964. On the distribution of the dolphin, Coryphaena hippurus L., in the Pacific Ocean and the Indian Ocean. Bulletin of the Japanese Society for the Science of Fish 30(6): 472-477. 
Lasso J \& L Zapata. 1999. Fisheries and biology of Coryphaena hippurus (Pisces: Coryphaenidae) in the Pacific coast of Colombia and Panama. Scientia Marina 63(3-4): 387-399.

Lombarte A \& J Lleonart. 1993. Otolith size changes related with body growth, habitat depth and temperature. Environmental Biology of Fishes 57: 297-308.

Madrid VJ \& R Beltrán. 2001. Longitud, peso y sexo del Dorado Coryphaena hippurus del litoral del Sinaloa, Nayarit y Baja California Sur, México. Revista de Biología Tropical (3-4): 931-938.

Massutí E, B Morales-Nin \& J Moranta. 1999. Otolith microstructure, age, and growth patterns of dolphin, Coryphaena hippurus, in the western Mediterranean. Fishery Bulletin 97(4): 891-899.

Montgomery DC, EE Peck \& GG Vining. 2004. Introducción al análisis de regresión lineal, 588 pp. Editorial Continental, México

Morales-Nin B, M Di Stefano, A Potoschi, E Massutí, P Rizzo \& S Gancitano. 1999. Differences between the sagitta, lapillus and vertebra in estimating age and growth in juvenile Mediterranean Dolphinfish (Coryphaena hippurus). Scientia Marina 63(3-4): 327-336.

Murray PA. 1985. Growth and mortality in the Dolphinfish Coryphaena hippurus caught off Saint Lucia, W.I. FAO Fishery Report 327: 47-153.

Nakamura I. 1985. Billfishes of the world. FAO Species Catalogue 5: 1-65. FAO, Rome.

Oxenford HA. 1999. Biology of the Dolphinfish (Coryphaena hippurus) in the western central Atlantic: a review. Scientia Marina 63(3-4): 277-301.

Oxenford HA \& W Hunte. 1983. Age and growth of Dolphin, Coryphaena hippurus, as determined by growth rings in otoliths. Fishery Bulletin 84(4): 906-909.

Palko BJ, GL Beardsley \& WJ Richards. 1982. Synopsis on the biological data on dolphin-fishes, Coryphaena hippurus Linnaeus and Coryphaena equiselis Linnaeus. NOAA Technical Report NMFS Circular 443: 1-25.

Panella G. 1980. Growth patterns in fish sagittae. In: Rhoads DC \& RA Lutz (eds). Skeletal growth for aquatic organism: biological records of environmental change, pp. 519-560. Plenum Press, New York.

Patterson KR \& J Martínez. 1991. Exploitation of the dolphin-fish Coryphaena hippurus L. off Ecuador: analysis by length-based virtual population analysis. Fishbyte 9: 21-23.

Pauly D. 1979. Theory and management of tropical multispecies stocks: a review with emphasis on the Southeast Asian demersal fisheries. ICLARM Studies Review 1: 1-35.

Pla C \& JM Pujolar. 1999. Genetic homogeneity of Dolphinfish (Coryphaena hippurus) in the western Mediterranean and the eastern Atlantic. Scientia Marina 63(3-4): 337-341.
Prager MH. 1987. Fishparm 3.0. Southwest Fisheries Science Center. California.

Ricker WE. 1975. Computation and interpretation of biological statistics of fish population. Bulletin on the fisheries research board of Canada, 382 pp. Department of the Environment Fisheries and Marine Service, Ottawa.

Rivera-Betancourt GA. 1994. Age and growth of Dolphinfish, Coryphaena hippurus L., in Puerto Rico as determined by otolith analysis. M.Sc. Theses, University of Puerto Rico, Mayaguez, 56 pp.

Rivera GA \& RS Appeldoorn. 2000. Age and growth of Dolphinfish, Coryphaena hippurus, off Puerto Rico. Fishery Bulletin 98: 345-352.

Rocha-Olivares A, M Bobadilla-Jiménez, S Ortega-García, N Saavedra-Sotelo \& JR Sandoval-Castillo. 2006. Variabilidad mitocondrial del Dorado Coryphaena hippurus en poblaciones del Pacífico. Ciencias Marinas 32: 569-578.

Rose CD \& WW Hassler. 1968. Age and growth of the dolphin, Coryphaena hippurus (Linnaeus), in North Carolina waters. Transactions of the American Fisheries Society 97: 271276.

Salgado-Ugarte IH, JL Gómez-Márquez \& B PeñaMendoza. 2005. Métodos actualizados para análisis de datos biológico-pesqueros, 240 pp. UNAM FES-Zaragoza, México.

Scherbachev YN. 1973. Biología y distribución de los Corifénidos (Pisces: Coryphaenidae). Voprosy Ikhtiologii 13(2): 219-230.

Schwenke KL \& JA Buckel. 2008. Age, growth, and reproduction of Dolphinfish (Coryphaena hippurus) caught off the coast of North Carolina. Fishery Bulletin 106: 8292.

Sparre P \& SC Venema. 1997. Introducción a la evaluación de recursos pesqueros tropicales - Parte 1: Manual. FAO Documento Técnico de Pesca 306/1 Rev.1: 1-420.

Taylor CC. 1959. Temperature and growth - the Pacific Razor Clam. Journal du Conseil 25(1): 93-101.

Thompson NB. 1999. Characterization of the Dolphinfish (Coryphaenidae) fishery of the United States western North Atlantic Ocean. Scientia Marina 63(3-4): 421-427.

Torres-Alfaro GM. 1996. Edad y crecimiento de Coryphaena hippurus (Linnaeus 1758) (Osteichthyes: Coryphaenidae), en el Sur de la península de Baja California, México. Tesis. Instituto Politécnico Nacional, Centro Interdisciplinario de Ciencias Marinas. La Paz, Baja California Sur, México, 71 pp.

Tripp-Valdez MA, FJ García de León, S Ortega-García, D Lluch-Cota, J López-Martínez \& P Cruz. 2010. Population genetic structure of Dolphinfish (Coryphaena hippurus) in the Gulf of California, using microsatellite loci. Fisheries Research 105: 172-177. 
Uchiyama JH, RK Burch \& SA Kraul. 1986. Growth of Dolphins, Coryphaena hippurus and C. equiselis in Hawaiian waters as determined by daily increments on otoliths. Fishery Bulletin 84(1): 186-191.

Von Bertalanffy L. 1938. A quantitative theory of organic growth (inquiries on growth laws. II). Human Biology 10(2): 181-213.

Walford LA. 1946. A new graphic method of describing the growth of animals. The Biological Bulletin 90(2): 141-147.

Weatherley AH \& HS Gill. 1987. The biology of fish growth, 429 pp. Academic Press, Harcourt Brace Jovanocich, Publishers, Ontario.

Wootton RJ. 1991. Ecology of teleost fishes, 404 pp. Chapman and Hall, London.
Zar JH. 1996. Biostatistical analysis, 662 pp. Prentice Hall, Upper Saddle River.

Zúñiga-Flores MS. 2002. Análisis de la estructura de tallas y relación peso-longitud del Dorado (Coryphaena hippurus, Linnaeus 1758) capturado en Mazatlán, Sinaloa durante 2000-2001. Tesis, Universidad Autónoma de Sinaloa, Mazatlán, Sinaloa, 40 pp.

Zúñiga-Flores MS. 2009. Dinámica poblacional del Dorado (Coryphaena hippurus) en Baja California Sur, México: implicaciones para su manejo. Tesis $\mathrm{PhD}$, Centro Interdisciplinario de Ciencias Marinas, BCS, México, 227 pp.

Received 2 September 2014 and accepted 11 August 2015

Associate Editor: Mauricio Landaeta D. 